\title{
A CASE OF EBSTEIN'S ANOMALY SURVIVING TO THE AGE OF 79
}

BY

\section{J. C. L. ADAMS AND REGINALD HUDSON}

From the West Middlesex Hospital, Isleworth, and the National Heart Hospital

In 1866 Ebstein described an uncommon congenital abnormality in which the tricuspid valve was situated below its normal site, thus reducing the size of the functioning right ventricle. Since then, many examples have been recorded, some with " patent foramen ovale," and others without it; the most recent was by Kerwin (1955), who described a case diagnosed during life. In Abbott's series of 16 examples of Ebstein's anomaly, the oldest survived to 56 years. The present case is believed to be the longest survival yet recorded, and was a woman of 79 who succumbed to suppurative cholangitis.

\section{Case Report}

A woman, aged 79, was admitted to the West Middlesex Hospital in October, 1954, with a diagnosis of obstructive jaundice. She had been well until two days before admission, and had never complained of shortness of breath or of swelling of the ankles, though a relative said that the patient did go blue on undue effort, particularly in cold weather.

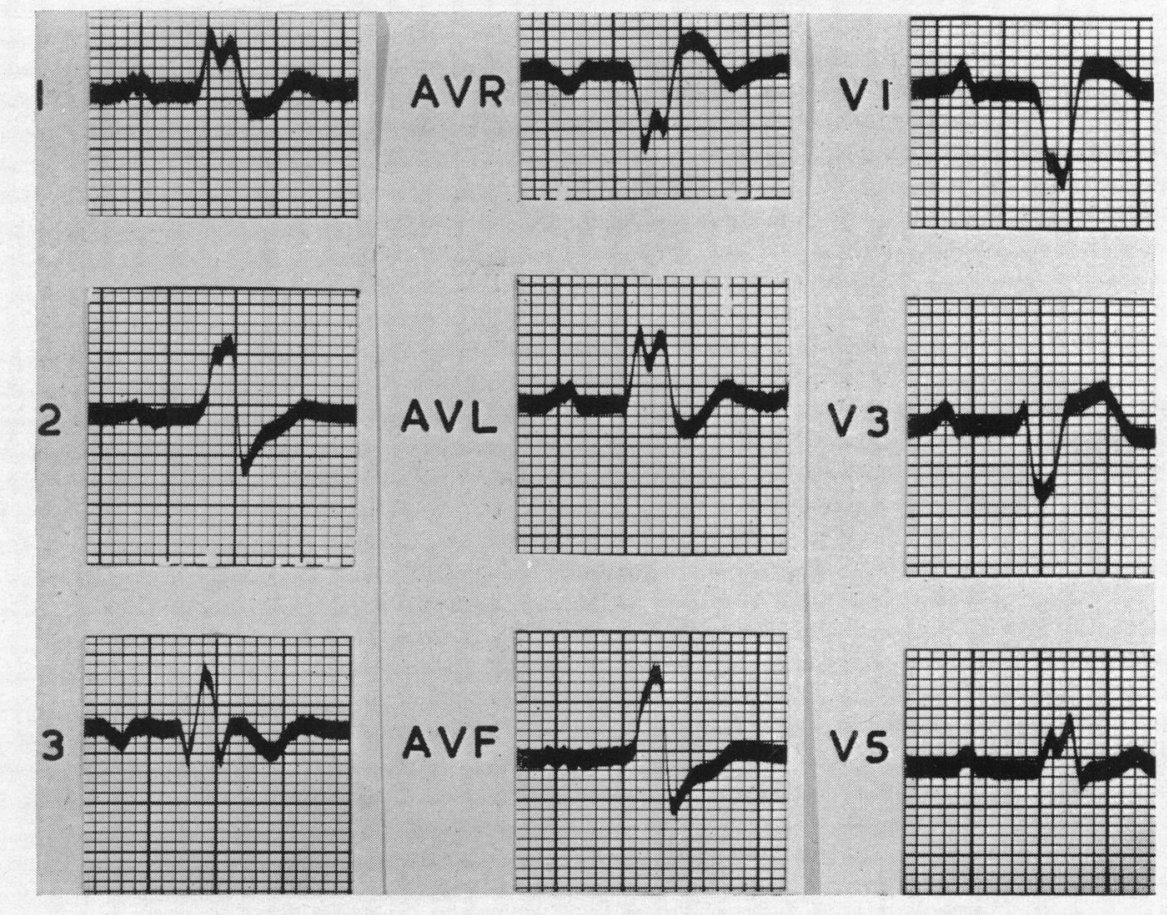

FIG. 1.-Electrocardiogram, showing long $P-R$ interval and left bundle-branch block 
On admission, the patient who was rather obese, was jaundiced and extremely ill, with a temperature of $101.4^{\circ} \mathrm{F}$., and a regular pulse of 120 a minute. There was no œdema. The jugular venous pressure was not raised and the apex beat was impalpable. The heart sounds were normal and no bruits were heard. The blood pressure was $135 / 80$. The urine contained bile salts and bile pigments. The electrocardiogram (Fig. 1) showed auriculo-ventricular block and left bundle-branch block. The serum bilirubin was 11.6 mg./100 ml., alkaline phosphatase 46.7 King-Armstrong units, and the hæmoglobin $18.9 \mathrm{~g} . / 100 \mathrm{ml}$. Circulation-time tests were unsuccessful. On the day following admission, the patient showed slight cyanosis of the lips, ears, and hands, and death occurred the same day.

Necropsy. This was performed by Dr. A. C. Counsell of the West Middlesex Hospital, who reported that the gall bladder was small and thick-walled, with an obstruction by a calculus $2 \times 1 \times 1$ in. The liver showed nutmeg pattern, and the larger bile ducts contained thick turbid bile. Histology of the liver showed a well marked chronic cholango-hepatitis, with irregular enlargement and chronic inflammatory cell infiltration of the portal tracts, and bile thrombi in the centrilobular canaliculi.

Dr. Counsell noted the right heart and tricuspid valve were grossly abnormal and kindly allowed one of us (R.H.) to make a further study of the heart. Fig. 2 is a view of the right heart of the specimen as received. Its weight was $431 \mathrm{~g}$.

The true right atrium (R.A.) was moderately dilated, with an ostium secundum atrial septal defect (O.S.) about $1.7 \mathrm{~cm}$. across, bridged by a filament of septum primum. The junction between true atrium and

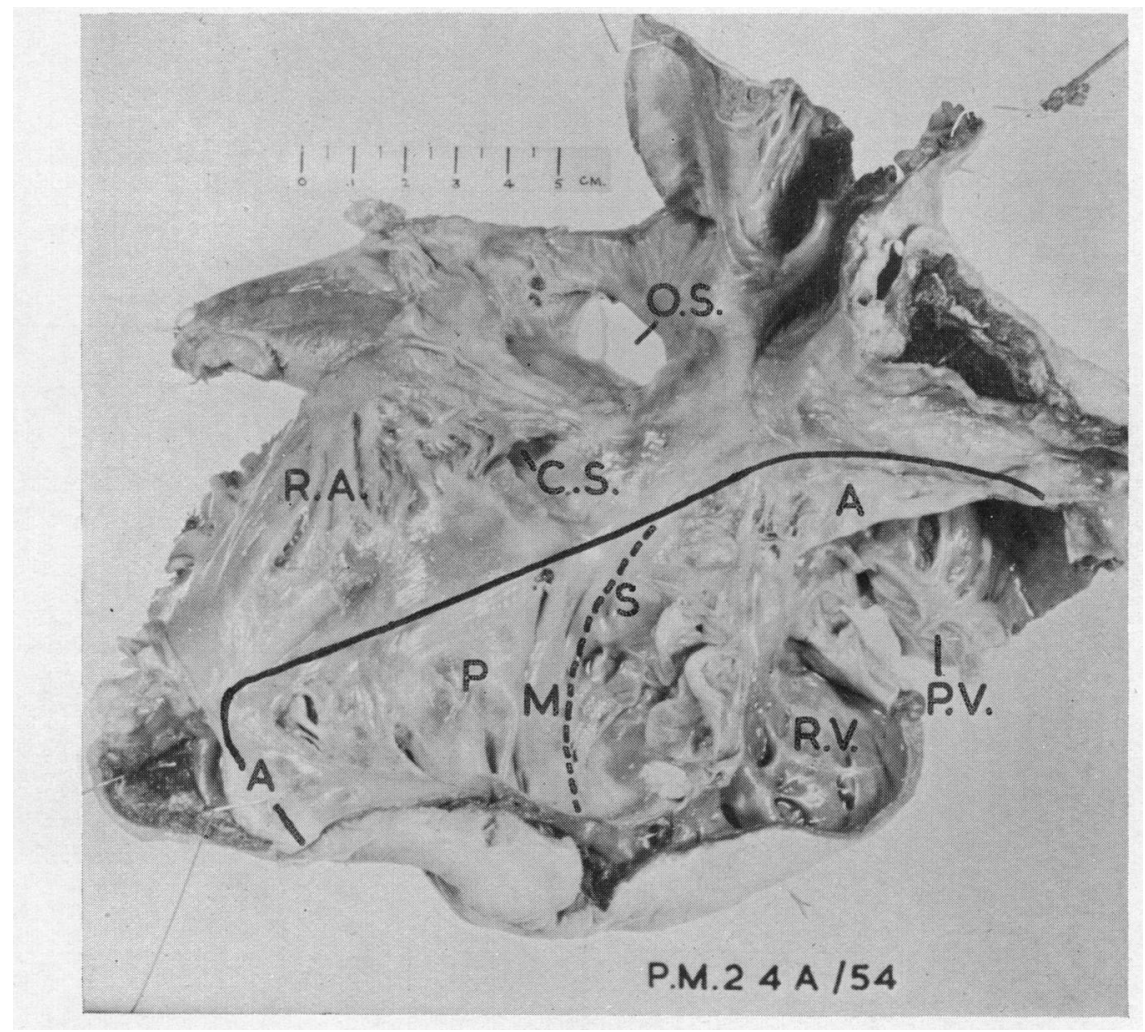

FIG. 2.-Ebstein's anomaly_right heart. R.A., right atrium; O.S., ostium secundum atrial septal defect; C.S., coronary sinus opening; $A A, P$, and $S$, anterior, posterior, and septal cusps of tricuspid value. Ventricular wall membranous at P. M, muscle band; R.V., functioning right ventricle; P.V., pulmonary valve. Continuous line indicates the atrio-ventricular junction and the normal origin of the tricuspid valve leaflets. Dotted line indicates the actual position of the valve ring, which joins the normal ring where the anterior cusp arises. 
ventricle was quite distinct (continuous line). The functioning right atrium included approximately the upper four-fifths of the ventricular chamber.

The tricuspid valve was quite abnormal and difficult to interpret. The anterior cusp which was cut across (AA) was thickened and arose from the normal valve ring (continuous line). The free edge was thickened but the cusp was mobile. The chordæ tendineæ and papillary muscles were rudimentary. The posterior cusp (P) appeared to be functionless and stuck down on to the ventricular wall. Its lower fringe was attached to a broad muscle band (M) by tiny, rudimentary chordæ tendineæ (not vis ible in the photograph). The wall of the ventricle underlying the cusp at $\mathbf{P}$ was translucent and almost devoid of muscle over an area about $4 \mathrm{~cm}$. across. Just below the muscle band (M) were a few calcified nodules. The septal cusp (S) was also largely fused to the ventricular wall, and its upper limit appeared to be in the position marked by the dotted line. The lower fringe of the septal cusp was oddly sacculated and showed a few rudimentary chordæ tendineæ and papillary muscles. The tricuspid valve orifice thus appeared to be functionally bicuspid, guarded in front by the thick lower edge of the anterior cusp and behind by the sacculated remnants of the septal cusp.

The funtioning right ventricle (R.V.) was reduced to about one-fifth of the true ventricle, and its wall was thinned to $2 \mathrm{~mm}$. The upper four-fifths of the true right ventricle was functioning as right atrium, and was mostly lined by adherent tricuspid valve cusps. The pulmonary valve (P.V.) ring was reduced to $6 \mathrm{~cm}$. The right anterior cusp was larger than the other two. The pulmonary trunk was correspondingly hypoplastic. The left atrium was moderately dilated and the left ventricle a little dilated and its wall $1 \cdot 3 \mathrm{~cm}$. thick. The mitral valve ring measured $9.0 \mathrm{~cm}$. and the cusps showed slight nodular marginal thickening. The chordæ tendineæ were normal. The aortic valve ring measured $7.5 \mathrm{~cm}$. and the cusps showed minimal thickening. There was mild atheroma of the aorta around the aortic valve. The coronary arteries were normally placed and showed only mild atheroma. The ductus arteriosus was closed (Dr. Counsell).

\section{Discussion}

Reference to embryological development suggests how the condition might arise. The atrioventricular valves arise by proliferation of subendocardial tissue of the atrio-ventricular canal and of the fused endocardial cushions (which divide the canal into tricuspid and mitral orifices) (Fig. 3A). These proliferations become excavated on their ventricular surfaces $(X)$ but remain connected to the ventricular wall by muscular strands which differentiate into papillary muscles and chordæ tendineæ. Irregular or partial failure of this excavation process would result in the affected part of the valve outgrowth seeming to be adherent to the ventricular wall, the free



A



B

FIG. 3.-Diagram to show how the excavation at $\mathrm{X}$ which occurs normally in (A), on the ventricular aspect of the proliferations which form the atrio-ventricular valves might be partially arrested in Ebstein's anomaly (B) so the valve cusps appear to arise well below the atrio-ventricular junction, and the chordæ tendineæ appear to be short 
portion of the cusp being much reduced so that the valve ring appears to be below the atrioventricular junction (Fig. 3B).

This case illustrates well that gross abnormality of the tricuspid valve and right ventricle in Ebstein's anomaly does not necessarily lead to a defective circulation, and it is quite compatible with a long healthy life.

\section{Summary}

The finding of Ebstein's anomaly is reported in a woman who survived to the age of 79 with no symptoms referable to the cardiovascular system, and who died from an unrelated disease.

We would like to express our thanks to Dr. N. F. Coghill for permission to publish this case and to Dr. A. C. Counsell for carrying out the necropsy.

\section{References}

Ebstein, W. (1866). Arch. Anat. Physiol. Wissensch. Med., 238.

Gould, S. E. (1953). Pathology of the Heart. Thomas, Springfield, U.S.A.

Hamilton, W. J., Boyd, J. D., and Mossman, H. W. (1952). Human Embryology. W. Heffer and Sons, Cambridge. Kerwin, A. J. (1955). Brit. Heart J., 17, 109. 